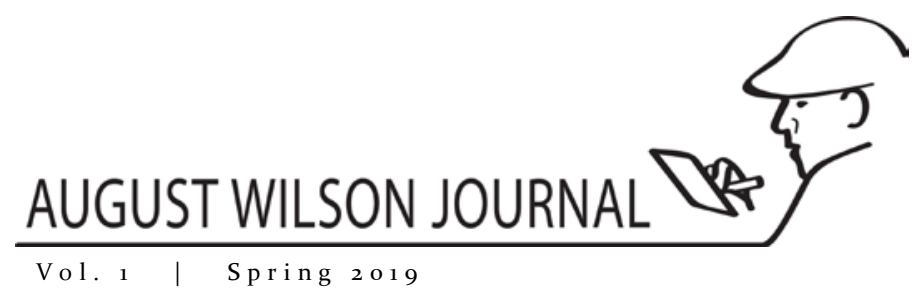

\title{
Dramaturg Interview: Martine Kei Green-Rogers on Radio Golf
}

\author{
By Melonnie Walker \\ Dramaturg and Social Media Coordinator for the August Wilson Society
}

I just love the fact that Wilson somehow manages to create families out of production teams.

- Martine Kei Green-Rogers

\begin{abstract}
An interview with Martine Kei Green-Rogers, dramaturg for Court Theater's (Chicago) production of Radio Golf.

Keywords

August Wilson, Chicago, Court Theatre, Radio Golf, Pittsburgh, Hill District, Dramaturgy, Martine Kei Green-Rogers
\end{abstract}

For its 2018-2019 season opener, Chicago's Court Theatre produced Radio Golf, the tenth installment in the American Century Cycle. Radio Golf addresses the internal conflict of the black middle-class in pursuit of the American dream. Set in a Hill District redevelopment office in 1997, the story follows Harmond Wilks, a real

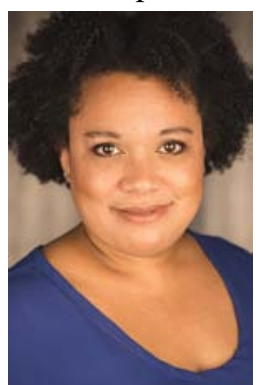

Martine Kei Green-Rogers estate mogul and emerging mayoral candidate who believes his commercial development plan will revive the old neighborhood. In this play, Wilson tackles the issue of gentrification in historic neighborhoods, and at what cost a community's improvement will upset its integrity.

The production was directed by Ron OJ Parson, who led the team through a successful and extended run from August 30-October 6. The production dramaturg was Dr. Martine Kei Green-

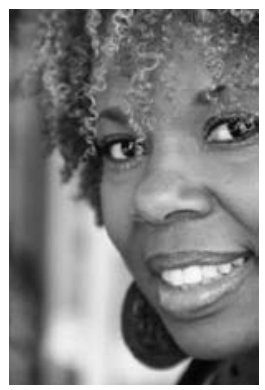

Mel Walker Rogers, who shared a rich account of her experience on this show.

MW: I know you and Ron Parson have a long history of working together at the Court Theatre. How many plays in the American Century Cycle have you worked on together?

MGR: Yes, I have worked with Ron in almost all of my other Court Theatre productions, including eight of the ten plays in the Cycle. 


\section{\begin{tabular}{l|ll} 
Vol.1 & Spring 2019
\end{tabular}}

MW: Did you begin your process of researching this play with any specific goals in mind from the director?

MGR: Because our last production of Wilson together at Court was Gem of the Ocean, we knew we were setting up the bookends of the Cycle for our audience. We knew that the last thing they would remember was 1904, and Ron wanted to make sure we were being super clear about where we are now and what has happened in the numerous decades since the last time we visited Pittsburgh. Also, Ron was really interested in the geography of the Hill District area, and wanted to be very specific about it. For example, since the set was designed in a way that allowed audience members to see the outside of the redevelopment office, he wanted to have an address added to the exterior wall of the set. With some deductive reasoning, I decided that it had to be somewhere within walking distance of the neighborhood, since people are coming in and out. Also, since the script refers to Centre and Kirkpatrick being "up on the corner," the office had to be downhill from those streets. That was actually one of the challenges of this play, because at times Wilson is both very specific, and yet not specific enough. In other plays of the cycle, we have very specific addresses, and names and anchors of places. So it was a little harder to do some of this work than it would normally be. But it just took a little bit of detective work to narrow it down.

MW: Did the cast and crew have any discussion about historic context from 1997, when this play is set?

MGR: We discussed what upper middle-class life looked like in the 199os in Pittsburgh. And we were surprised by things like how far we've advanced in technology since then. For example, we kept forgetting how much time had passed and the fact that you no longer have to pull your antenna out of your phone. But I think in a lot of ways we were considering more philosophical questions rather than historical events. Like what does this play have to say about black life now? At the first reading, I remember that moment when Harmond talks about the person being killed by the officer, and the officer still getting his bonus and his thanksgiving turkey. Those conversations just really hit us in ways that I don't think any of us realized they would. So if anything, we found that even though the events were rooted in 1997, little has changed.

MW: Did you have any definitive themes about Radio Golf that you felt a need to emphasize with the cast and crew?

MGR: Yes, specifically about the place that this show holds in the overall canon. So back to this idea of it being part of the bookends and literally at the end of his career because of his death. So we discussed what that means for the play and the conversations it brings up. We are wrestling with some of the same things today, which is fascinating because the play is set over 20 years ago. We also spent a lot of time talking about the wrapping up of the history of 1839 Wylie, and the generation and the legacy. And connecting those moments when we discover Aunt Ester in Two Trains Running is the mother of Elder Barlow in Radio Golf.

MW: Were there any scenes or parts of the play that really resonated with you personally or became a favorite?

MGR: My favorite moment of the entire play is the very end with the fight between Roosevelt and Harmond. The reason is that Wilson really hit the nail on the head for some of the issues that we are still debating right now. For example, at what cost in our contemporary society does success have? And what does that mean when you're from a historically under-represented and/or marginalized group? Does success equal being able 
W A L K E R: D R A M A T U R I N T E R V I E W : M A R T I N E K E I G R E N ROGERS O N R A D O G O L F

August Wilson Journal | Vol. 1 Spring 2019

to replicate white life and status, or is it something different? And I think the argument between those two ideas are very compelling. I remember when I first read the play years ago I thought Roosevelt was so terrible. And not that I necessarily agree with Roosevelt now, but looking at him in today's context, there's a part of me that could see how someone could get to that point in a way that I could not have fathomed ten years ago.

MW: What did you anticipate the audience response would be during talkback sessions based on your previous experience at Court Theatre?

MGR: The thing that's interesting about Court Theatre talkbacks, is that since Court sits on the University of Chicago's campus, there's a lot of campus engagement with their productions. So it's a very learned audience. And I would say that about $80 \%$ of the people would have read this play, if not the entire Wilson cycle. So you definitely don't get the standard talkback questions, like "how did you learn all those lines?" Court audiences are more likely to ask questions like, so "I see you made this choice in Act II, scene i," and actually make script references while giving their feedback.

MW: How would you describe the actual audience engagement after previews? Did the audience members have any poignant questions or maybe concerns that we still face today regarding gentrification?

MGR: This is such a juicy question. Our audiences were both shocked and intrigued by how timely this play is, considering when Wilson wrote it. Many, including Chris Jones of the Chicago Tribune, realized the play was extremely prophetic. Our audiences were really interested in the conversations we had to prepare for this production. And they also wanted to dig into some very specific regional issues like what does it mean for this play to be done on University of Chicago's campus, which has its own interesting history of gentrification on the south side of Chicago.

MW: Is there anything else you'd like to share with readers about your dramaturgical experience working with the cast and crew?

MGR: One of the things that I think Wilson is really good at, that just transfers into any rehearsal process, is his sense of community. I have never worked on a Wilson play after which somehow we don't all become family. It's so interesting because I have done plenty of shows where everyone is kind and cordial and friendly, but I would say $99 \%$ of the time if you're working on a Wilson piece you're going to be hanging out with these people after rehearsal, going out, cooking food together and doing all sorts of things that you normally would not do in shows written by other authors. So I just love the fact that Wilson somehow manages to create families out of production teams.

MW: Yes, I've been watching the posts on Court Theatre's Facebook page, where you allow your followers to get a peek of your rehearsal process and I saw that you all went golfing together. What was that like?

MGR: That was so great, and almost everyone in the production team participated. Even people that didn't necessarily have to be there, like one of the assistants and a few people from marketing, but everyone wanted to participate and hang out. And as we were there talking about the show and Roosevelt's radio segment, there were other people on the golf course listening and they wanted to know what we were talking about. Before we knew it, we had a crowd of people around us and we were able to pass out information about the show. So even being out together to learn about golfing, we managed to create a community 


\section{\begin{tabular}{l|ll} 
Vol. 1 & Spring 2019
\end{tabular}}

with the people who were there. And I think that is something very special that Wilson does. He just figured out, somehow beautifully, how to create family out of people.

MW: What a fitting observation about Wilson's work and the impact it has on people. Thank you so much for sharing this experience with us. I believe fellow dramaturgs will benefit from hearing your perspective.

Dr. Martine Kei Green-Rogers is currently President of the Literary Managers and Dramaturgs of the Americas and an Assistant Professor at SUNY New Paltz. She obtained her PhD from the Department of Theatre and Drama at the University of WisconsinMadison. Prior to studying at UW-Madison, she received her B.A. in Theatre from Virginia Wesleyan College and her M.A. in Theatre History and Criticism from The Catholic University of America.

Her dramaturgical credits are extensive, and include the following works by Wilson: productions of Radio Golf, Gem of the Ocean, Seven Guitars at the Court Theatre (Chicago, IL); productions of Fences at the Pioneer Memorial Theatre and the Oregon Shakespeare Festival (Ashland, OR).

Her most recent publications include the article "Talkbacks for 'Sensitive Subject Matter' Productions: The Theory and Practice" in the Routledge Companion to Dramaturgy and the upcoming publication of "Translating' Shakespeare: A History of The Two Noble Kinsmen through the University of Utah and the Oregon Shakespeare Festival's Play on! Project" in Theatre History Studies.

\section{Works Cited}

Wilson, August. Radio Golf. Theatre Communications Group. 2007.

\section{Author Bio}

Ms. Melonnie Walker is a dramaturg and social media coordinator for the August Wilson Society.

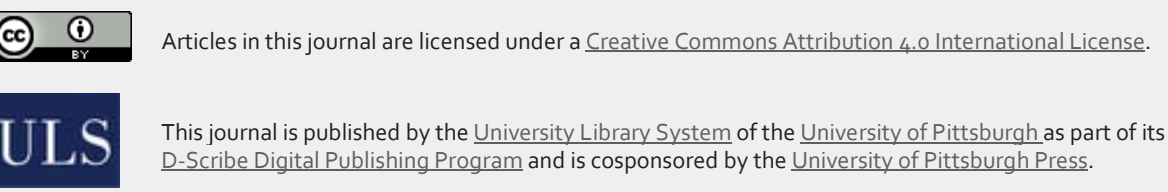

augustwilson.pitt.edu

DOI 10.5195/awj.2019.15

ISSN 2577-7432 (online) 